\title{
Research on the Relationship between Transformational Leadership and Government Service Innovation
}

\author{
Dingxiang Chen, Xiaobao Peng \\ School of Public Affairs, University of Science and Technology of China, Beijing, China \\ Email: cdx1217@foxmail.com
}

How to cite this paper: Chen, D. X., \& Peng, X. B. (2017). Research on the Relationship between Transformational Leadership and Government Service Innovation. Open Journal of Leadership, 6, 82-94. https://doi.org/10.4236/ojl.2017.62005

Received: May 16, 2017

Accepted: June 26, 2017

Published: June 29, 2017

Copyright (C) 2017 by authors and Scientific Research Publishing Inc. This work is licensed under the Creative Commons Attribution International License (CC BY 4.0).

http://creativecommons.org/licenses/by/4.0/

\begin{abstract}
In this research, the thinking is carried out in accordance with logical order. The results of this study show that: the four dimensions of transformational leadership have different effects on the service innovation of government departments. On the basis of the results, this paper puts forward four specific strategies and methods to achieve and improve the service innovation of government departments, and discusses the shortcomings of this study and future research directions.
\end{abstract}

\section{Keywords}

Transformational Leadership, Explicit Knowledge Acquisition, Tacit Knowledge Acquisition, Government Service Innovation

\section{Introduction}

The government faces more complex social and environmental issues, the overall goal of deepening reform, the construction of learning government and service-oriented government put forward higher expectations for government management and service innovation (Berry, 1994; Barzelay \& Jacobsen, 2009). Government departments continue to improve the level of management and service innovation, not only conducive to efficient and smooth operation of the department, but also having an important impact on the economic and social development of the region as a whole (Borins, 2012). In China scenario, the government departments are implementation of responsibility system; department leadership cannot be ignored in policy formulation and implementation, therefore, influence factors of government service innovation cannot ignore the leadership. Since the 1990s, China had set off a wave of government innovation, and governments tend to carry out various innovative practices all over the 
world (Wu et al., 2011). The level of government innovation has become one of the important criteria for the promotion and appointment of government cadres, leading to the government leaders at all levels of government departments tend to innovation. This paper wants to discuss the relationship between transformational leadership and government service innovation.

Previous studies on the relationship between leadership and organizational performance are mainly focused on the enterprise level, although there are some issues in public management research, the lack of academic attention. For the service innovation of government departments, there is a lack of detailed classification and discussion; the government leaders make the choice of innovation model, which is also affected by many factors (Berry, 1994; Hartley, 2005). Compared with previous studies, this study has two innovations: First, the research on transformational leadership and knowledge acquisition is classified, divided into exploratory service innovation and exploitative service innovation, tacit knowledge acquisition and explicit knowledge acquisition, to explore the "transformational leadership-government service innovation" mechanism. To some extent, it enriches the theory of transformational leadership and government service innovation. Second, this research not only discusses the overall concept of transformational leadership, but on the four dimensions of transformational leadership in government service innovation choice, mainly because the four dimensions of transformational leadership are very different in connotation.

The value orientation of government leaders is different from that of private enterprise leaders. The leaders of government departments take the social fair value instead of the economic value as the main value. At the same time, the private sector and the public sector are intrinsically consistent, emphasizing that leaders play an important role in management, service and innovation in this sector (Fernandez, 2004). This consistency and difference lead to the empirical confusion for the writer: what are the differences between the leaders in the government departments and the leaders in the management of enterprises? Could the study of leadership in government departments draw on private sector studies? From the perspective of leadership, what is the concrete way for government departments to realize their own service innovation? What factors influence the relationship between leadership and government service innovation?

\section{Transformational Leadership and Government Service Innovation}

Through sorting out and summarizing the relevant theories and literatures, we can conclude that there have been some achievements about transformational leadership, knowledge acquisition and the service innovation of government departments, mainly reflected in the following aspects.

Firstly, in the study of transformational leadership, the existing literature mainly focuses on qualitative research on concept definition, leadership style and leadership influence (Bennis \& Nanus, 1985; Barbuto \& Burbach, 2006). 
Foreign scholars have gradually adopted quantitative methods to study government leadership (Zacher et al., 2011; Kim, 2014). However, under the Chinese situation, there is a lack of quantitative research methods to study the mechanism of leadership in government departments. Through the review of the literature, we found that the research on the relationship between transformational leadership and government service innovation is relatively small, while discussed the mechanism between them standing on the Chinese situation is blank. At the same time, this study divides the transformational leadership into dimensions, and then explores the impact of different dimensions on the service innovation of government departments (Burns, 1978; Bass, 1985; Bennis \& Nanus, 1985).

Second, in the study of government innovation, domestic and foreign scholars think that the government innovation is focusing on the process of innovation, not only the innovation results, the government is the biggest supplier of public service (Damanpour, 1988; Berry, 1994; Barzelay \& Jacobsen, 2009; Wen, 2014). This study mainly adopts this view, which is mainly about the government service innovation, which mainly refers to the innovation of the way and process of the service provided by the government. This study divides it into two types: exploratory service innovation and exploitation service innovation, and probes into two types of government service innovation.

Third, knowledge acquisition as an important factor affects innovation performance. But in the study of antecedents of knowledge acquisition, scholars pay more attention to the characteristics of knowledge, organization and network (Harvey et al., 2010; Pinjani \& Palvia, 2013; Titi Amayah, 2013; De Vries et al., 2015; Reagans \& McEvily, 2003), and ignore the leader characteristics that influence knowledge acquisition in organizations (Richards \& Duxbury, 2015). This study attempts to study the relationship between transformational leadership and government service innovation from the perspective of knowledge acquisition, so as to understand the mechanism. At the same time, according to the nature of knowledge, the knowledge acquisition will be divided into tacit knowledge acquisition and tacit knowledge acquisition, corresponding to the two kinds of government service innovation category, namely the exploratory service innovation and exploitative service innovation.

\section{Conceptual Model}

Figure 1 presents our conceptual model. In the following paragraphs we discuss, first, how transformational leadership influences government service innovation, second, how transformational leadership behaviors are associated with knowledge acquisition, and, third, how knowledge acquisition influence government service innovation in teams.

\subsection{Transformational Leadership and Government Service Innovation}

Wright et al. (2012) point out that transformational leadership refers to leadership behaviors that focus on strategic decisions, adapt to environmental change, 


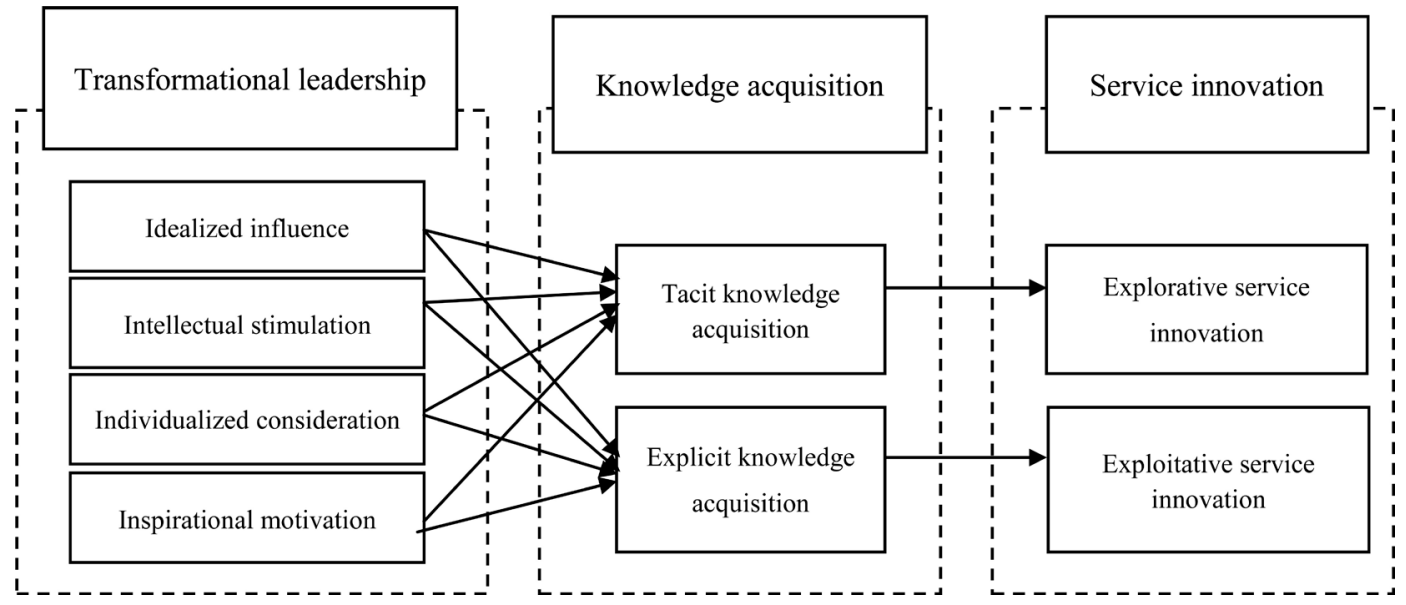

Figure 1. Theoretical model.

improve complexity and innovation levels, and constantly meet changing demands. Relevant literature holds that transformational leadership influences organizational performance in three main ways. First, change oriented leadership improves organizational performance by improving the organization's adaptability and responsiveness to the external environment. Second, change oriented leaders are able to identify profitable, forward-looking strategic innovations that are good for organizational development. Third, change oriented leadership can encourage employees to actively seek creative ideas to cope with organizational problems (Bass, 1985).

Transformational leaders have the ability to challenge assumptions, take risks and motivate others, and agree with exploratory service innovation. Transformational leaders achieve the implementation of exploratory innovation through information feedback from effective communicators (Vera \& Crossan, 2004). First, through the display of their idealized influence, transformational leaders establish themselves as example, and will be able to transfer this tendency to innovation behavior to the members of the organization (Waldman \& Yammarino, 1999). Second, through intellectual stimulation, transformational leaders encourage subordinates should be thinking "outside the box", and encourage to look at the problem in different angles (Sosik et al., 1997). Third, through individualized consideration, transformational leaders pay close attention to employee growth and needs, to help employees occupation planning, through the consideration to make the members of the organization feel the importance of transformational leadership on reform and innovation, thus affecting the whole tendency of government departments in the choice of exploratory service innovation. Fourth, though inspirational motivation, transformational leaders combine personal identity with collective identity. The main responsibility of transformational leaders is to change the individual consciousness of subordinates to serve organizational goals and to enhance the intrinsic motivation of subordinates to pursue exploratory innovation (Jansen, Vera, \& Crossan, 2009).

Although transformational leadership has a positive impact on exploratory service innovation, it can also be conducive to exploitative innovation. First, 
transformational leadership through the leader's idealized influence to convey administrative tasks and responsibilities to subordinates, to handle the tasks only need to use the type of service innovation, which can improve the work efficiency. Second, through intellectual stimulation, transformational leaders can change working methods, so as to solve administrative problems. Third, through individualized consideration, transformational leaders and subordinates form relatively good personal relationships, so that subordinates can really identify with organizational idea, and achieve organizational goals. Fourth, through inspirational motivation, transformational leaders can map out the organization's blueprint and identify clear development goals for the organization. In the context of government innovation, Leaders will balance the risks and performance of innovation development, which will enable transformational leaders to take into account the two types of service innovation. Based on the above discussion, we propose the following hypothesis:

H1: Transformational leadership has a positive impact on exploratory service innovation in government sectors. Among them, idealized influence (H1a), intellectual stimulation ( $\mathrm{H} 1 \mathrm{~b})$, individualized consideration (H1c) and inspirational motivation (H1d) have a positive impact on exploratory service innovation.

H1: Transformational leadership has a positive impact on exploitative service innovation in government sectors. Among them, idealized influence (H1a), intellectual stimulation ( $\mathrm{H} 1 \mathrm{~b})$, individualized consideration (H1c) and inspirational motivation (H1d) have a positive impact on exploitative service innovation.

\subsection{Transformational Leadership and Knowledge Acquisition}

Cai et al. (2013) point out that transformational leadership has a positive effect on knowledge acquisition, transfer and sharing, and then influences the whole knowledge acquisition in the level of the team. First, through the idealized influence, transformational leaders can enhance the team identity, so that can enhance mutual trust in the organization, which prompted the organization to become a knowledge exchange platform playing an important role in the internalization of knowledge. In this process, explicit knowledge acquisition and tacit knowledge acquisition are promoted positively. Second, through intellectual stimulation, transformational leaders encourage subordinates to use new methods and new segments to cope with problems at work. In this process, it is beneficial for the organization members to acquire and disseminate all kinds of knowledge. Third, through inspirational motivation, transformational leaders motivate subordinates in order to strive for the interests of the organization. The collective sense of honor is good for knowledge sharing and accessing (Kark \& Shamir, 2002). Fourth, transformational leaders enhance individual job satisfaction and citizenship behavior through the individualized consideration, while organizational members' attitudes towards knowledge resources determine knowledge acquisition at the same time. From this, we can see that transforma- 
tional leadership has a positive role in promoting knowledge sharing and acquisition among team members. Birkinshaw (2001) believes that only by acquiring and sharing explicit knowledge and tacit knowledge at the same time, which have a positive impact on the improvement of knowledge management level of the whole organization. In order to improve the level of knowledge management, transformational leaders in government departments tend to acquire explicit knowledge and tacit knowledge at the same time, so as to achieve the balance of different types of knowledge. Through the above statement, we have the following hypothesis:

H3: Transformational leadership has a positive influence on tacit knowledge acquisition. Among them, idealized influence (H3a), intellectual stimulation $(\mathrm{H} 3 \mathrm{~b})$, individualized consideration $(\mathrm{H} 3 \mathrm{c})$ and inspirational motivation $(\mathrm{H} 3 \mathrm{~d})$ have a positive impact on tacit knowledge acquisition.

H4: Transformational leadership has a positive influence on explicit knowledge acquisition. Among them, idealized influence (H4a), intellectual stimulation ( $\mathrm{H} 4 \mathrm{~b})$, individualized consideration $(\mathrm{H} 4 \mathrm{c})$ and inspirational motivation (H4d) have a positive impact on explicit knowledge acquisition.

\subsection{Knowledge Acquisition and Government Service Innovation}

In certain situations, organizations with more knowledge are more likely to find solutions to solve problems (Mol et al., 2008). The organization's knowledge stock plays an important role in organizational decision making. However, little research has focused on how knowledge is created, and how knowledge creation processes are managed (Girard \& McIntyre, 2010). According to Bloodgood \& Salisbury (2001), each organization must identify the specific location of the knowledge stock, thereby ensuring the creation, transfer and protection of knowledge with the right methods. Organizational performance achieved by knowledge is more dependent on the availability of knowledge (Girard \& McIntyre, 2010). In the government sector, the knowledge acquisition can make the organization get more knowledge stock, to innovate government management mod$\mathrm{el}$, which is conducive to cope with the increasingly complex social issues and matters, gradually increase public satisfaction, improve the management level, so as to achieving the goal of public interest (Yu, 2006).

As a higher degree of innovation, exploratory service innovation puts forward higher requirements for the tacit knowledge. Because of the relatively low mobility of personnel, the government departments are lack of tacit knowledge. In order to meet the needs of the exploration service innovation, the government must pay attention to the acquisition of tacit knowledge. Valle \& Vázquez-Bustelo (2009) believes that the tacit knowledge can significantly enhance the exploratory innovation performance.

The process of organizing the application of existing knowledge to produce new knowledge is primarily through the use of exploitative innovation (Popadiuk \& Choo, 2006). Nonaka \& Takeushi (1995) proposed a SECI model of explicit knowledge and tacit knowledge, scholars combine the fusion and inter- 
nalization with exploitative innovation together, and the explicit knowledge acquisition of innovation have a positive impact on the incremental service innovation. Based on the above discussion, we propose the following hypothesis:

H5: Tacit knowledge acquisition has a positive impact on the government exploratory service innovation.

H6: Explicit knowledge acquisition has a positive impact on government exploitative service innovation.

\section{Methods}

The main method used in this study is questionnaire survey. The main subjects of questionnaire survey are government leaders and department staff. In this study, the scale was revised and improved on the basis of drawing on the more mature scales at home and abroad, and the factor analysis of the scale was completed, and the validity and reliability of the scale were proved. After this, the main variables in this study of transformational leadership, knowledge acquisition, government service innovation is measured. The MPA class students of the school fill the questionnaire, then we modify and improve the questionnaire, so as to form the final version of the questionnaire. Finally, through the assistance of teachers and friends, we launched questionnaires officially. In order to make the results more reasonable and scientific, the questionnaire is divided into government leader questionnaire (A questionnaire) and general staff questionnaire (B questionnaire), department leaders to evaluate the knowledge acquisition and service innovation, and general staff evaluate the transformational leadership. In this paper, an independent encoding is given to each questionnaire to achieve the matching between the A questionnaire and the $\mathrm{B}$ questionnaire, so as to avoid data confusion. The 5 point Likert scale was used for all variables. The research uses SPSS19.0 and LISERL8.0 to analyze the data and verify the above hypothesis.

\subsection{Measures}

Transformational leadership. The Multifactor Leadership Questionnaire is used in this study to measure transformational leadership, including idealized influence, intellectual stimulation, individualized consideration and inspirational motivation. This research has 12 projects for transformational leadership measurement. The measurement items of idealized influence include: (1) The leaders emphasize the importance of the concept of collectivism in the tasks; (2) I am very trust leaders' ability; (3) I would like to share responsibility with leaders. The measurement items of intellectual stimulation include: (1) My leaders always encourages me to analyze problems from different perspectives; (2) My leaders always encouraged me to solve problems from different perspective; (3) My leaders always provide new ideas and viewpoints when I complete the tasks. The measurement items of individualized consideration include: (1) My leaders will spend a lot of time to help and guide me; (2) My leaders can recognize that each employee's growth and development needs are different; (3) My leaders will 
give different care and help for different employees. The measurement items of inspirational motivation include: (1) My leaders is always passionate about the future goals; (2) My leaders are confident with of achieving the goals of my work; (3) My leaders always encourage me to finish the task ahead of time.

Knowledge acquisition. Since the problem studied in this paper is the knowledge acquisition in the context of Chinese government, the measurement of knowledge acquisition is adjusted in this study. We draw on previous scholars' research (Norman, 2004), the measurement items of explicit knowledge acquisition include: (1) The organization obtains relevant information about the system of organization and archives of the department; (2) The organization obtains information about the work steps and the process from the members of the department; (3) The organization can get specific measures from the members of the department; (4) The organization can get specific content of organization for organization service from members of the department. The measurement items of tacit knowledge acquisition include: (1) The organization can get new skills about development and use of new service from members of the department; (2) The organization can get new skills about management from members of the department; (3) The organization internalize the organizational culture from members of the department; (4) The organization department can obtain service problem skills from members of the department.

Government service innovation. The measurement of government service innovation mainly referring to the previous scholar's research (Jansen et al,, 2009; Tan, 2016). The measurement items of exploratory service innovation include: (1) My department can accept more requirements transcend existing service; (2) My department often provide new services; (3) My department often adopt the new service model and management model; (4) My department often learn new practice from other departments. The measurement items of exploitative service innovation include: (1) My department often carry out the adjustment and upgrading to existing services; (2) My department often improve the efficiency of service and management; (3) My department often pays attention to reduce the service cost; (4) My department often pays more attention to the existing regulations system.

\subsection{Data Collection}

The sample of this study selected from the government departments. In the course of the questionnaire collection, we distinguish the government leader questionnaire and general staff questionnaire. The questionnaire investigation lasted 3 months, making full use of teachers and students in the MPA class of the University of Science and Technology of China. The final recovery of 300 questionnaires, excluding 40 invalid questionnaires, 260 valid questionnaires, the effective recovery rate is $86.67 \%$.

\subsection{Reliability and Validity Analysis}

Each variable's Cranbach's alpha is greater than 0.8 , indicating that the scale of 
this study has high reliability. At the same time, we also need to consider the validity, the KMO value is equal to 0.884 , Bartlett's spherical test results show that the chi-square value is equal to 2335.104 , the significance level is less than 0.001 .

\section{Results}

The descriptive statistics and inter-correlations of the study variables are shown in Tables 1-3. From model 2 in Table 2 and Table 3, the results show that transformational leadership has a positive influence on government exploratory service innovation and exploitative service innovation $(\beta=0.846, p<0.01, \beta=$ $0.655, p<0.01$ ). Among them, idealized influence, intellectual stimulation and individualized consideration have a positive effect on government exploratory innovation $(\beta=0.569, p<0.01 ; \beta=0.085 p<0.01 ; \beta=0.332, p<0.01)$, but the role of inspirational motivation influences on the exploratory service innovation is not significant $(\beta=0.029, p>0.05)$ idealized influence and individualized consideration has positive effects on exploitative service innovation $(\beta=0.250, p$ $<0.01 ; \beta=0.492, p<0.01$ ), but the role of intellectual stimulation and inspirational motivation on the exploitative service innovation is not significant $(\beta=$ $-0.036, p>0.05 ; \beta=0.038, p>0.05$ ). As a result, H1, H1a, H1b, H1c, H2, H2a, $\mathrm{H} 2 \mathrm{c}$ are supported, and $\mathrm{H} 1 \mathrm{~d}, \mathrm{H} 2 \mathrm{~b}$, and $\mathrm{H} 2 \mathrm{~d}$ are not supported.

From model 4 in Table 2, transformational leadership has a significant positive effect on explicit knowledge acquisition and tacit knowledge acquisition $(\beta=$ $0.724, p<0.01, \beta=0.814, p<0.01$ ). Among them, inspirational motivation and individualized consideration have a significant impact on explicit knowledge acquisition $(\beta=0.236, \mathrm{p}<0.01 ; \beta=0.497, p<0.01)$, and the effects of idealized influence and intellectual stimulation is not significant $(\beta=0.083, p>0.05 ; \beta=$ $0.045, p>0.05)$. Among them, idealized influence, intellectual stimulation, individualized consideration and inspirational motivation have significant positive effect on tacit knowledge acquisition $(\beta=0.158, \mathrm{p}<0.01 ; \beta=0.095, p<0.01 ; \beta=$ 0.209, $p<0.01 ; \beta=0.519, p<0.01$ ). Therefore, H3, H3a, H3b, H3c, H3d, H4, $\mathrm{H} 4 \mathrm{c}$ and $\mathrm{H} 4 \mathrm{~d}$ are supported, while $\mathrm{H} 4 \mathrm{a}$ and $\mathrm{H} 4 \mathrm{~b}$ are not supported.

According to model 8 in Table 2 and Table 3, we can learn that the tacit knowledge acquisition has a positive effect on government exploratory service innovation $(\beta=0.178, p<0.01)$; explicit knowledge acquisition has a positive effect on exploitative service innovation $(\beta=0.604, p<0.01)$. Therefore, $\mathrm{H} 5$ and H6are supported.

\section{Discussion}

\subsection{Conclusion}

First, cultivating and promoting the leadership of government departments play an important role in the improvement of innovation performance. This paper studies the impact of transformational leadership on government innovation performance, and transformational leadership mainly through knowledge acquisition, which enhance service innovation. Second, through the above data results, we can see that the leadership of government departments has an impor- 
Table 1. Descriptive analysis, correlation analysis, and discriminant validity analysis of major variables.

\begin{tabular}{|c|c|c|c|c|c|c|c|c|c|c|c|c|c|c|c|}
\hline Variables & Mean & S.D & 1 & 2 & 3 & 4 & 5 & 6 & 7 & 8 & 9 & 10 & 11 & 12 & 13 \\
\hline 1 & 1.10 & 0.30 & N.A. & & & & & & & & & & & & \\
\hline 2 & 3.09 & 0.847 & -0.203 & N.A. & & & & & & & & & & & \\
\hline 3 & 3.33 & 0.740 & 0.161 & -0.111 & N.A. & & & & & & & & & & \\
\hline 4 & 1.83 & 0.961 & -0.047 & $0.209^{*}$ & $-0.233^{*}$ & N.A. & & & & & & & & & \\
\hline 5 & 3.375 & 0.8879 & $-0.267^{\star *}$ & $-0.140^{\star *}$ & $0.066^{* *}$ & -0.109 & $(0.84)$ & & & & & & & & \\
\hline 6 & 3.450 & 1.174 & $-0.266^{\star *}$ & $-0.180^{\star *}$ & $0.274^{* *}$ & -0.115 & $0.800^{* *}$ & $(0.76)$ & & & & & & & \\
\hline 7 & 3.571 & 1.095 & $-0.189^{\star *}$ & $0.151^{*}$ & $0.168^{* *}$ & -0.038 & $0.546^{* *}$ & $0.301^{* *}$ & $(0.77)$ & & & & & & \\
\hline 8 & 2.933 & 1.209 & $-0.201^{\star *}$ & $-0.221^{\star \star}$ & -0.168 & -0.085 & $0.823^{* *}$ & $0.751^{* *}$ & $0.241^{* *}$ & $(0.94)$ & & & & & \\
\hline 9 & 3.547 & 1.039 & $-0.169^{\star *}$ & $-0.171^{\star *}$ & $0.146^{* *}$ & -0.098 & $0.813^{* *}$ & $0.725^{\star *}$ & $0.207^{\star *}$ & $0.616^{\star *}$ & $(0.86)$ & & & & \\
\hline 10 & 3.542 & 0.879 & $-0.202^{\star *}$ & -0.802 & $0.192^{\star *}$ & -0.259 & $0.745^{\star *}$ & $0.687^{\star *}$ & $0.280^{\star *}$ & $0.702^{\star *}$ & $0.634^{\star *}$ & $(0.86)$ & & & \\
\hline 11 & 3.371 & 0.867 & $-0.355^{\star *}$ & $-0.139^{*}$ & $0.152^{*}$ & $-0.157^{*}$ & $0.801^{* *}$ & $0.606^{* *}$ & $0.353^{* *}$ & $0.834^{* *}$ & $0.726^{* *}$ & $0.807^{* *}$ & $(0.88)$ & & \\
\hline 12 & 3.284 & 0.996 & $-0.321^{\star *}$ & $-0.167^{* *}$ & $0.241^{* *}$ & -0.108 & $0.711^{* *}$ & $0.721^{* *}$ & $0.368^{* *}$ & $0.811^{* *}$ & $0.697^{* *}$ & $0.722^{* *}$ & $0.850^{* *}$ & $(0.85)$ & \\
\hline 13 & 3.397 & 0.923 & $-0.370^{\star *}$ & $-0.187^{\star *}$ & $10.62^{* *}$ & 0.068 & $0.800^{* *}$ & $0.665^{* *}$ & $0.282^{* *}$ & $0.853^{* *}$ & $0.661^{* *}$ & 0.686 & $0.814^{* *}$ & $0.792^{* *}$ & $(0.72)$ \\
\hline
\end{tabular}

Note: 1. gender; 2. age; 3. education background; 4. years; 5. transformational leadership; 6. idealized influence; 7. intellectual stimulation; 8. individualized consideration; 9. inspirational motivation; 10. explicit knowledge acquisition; 11 tacit knowledge acquisition; 12 exploratory service innovation; 13. exploitative service innovation. ${ }^{* *}: p<0.01 ; *: p<0.05$.

Table 2. Analysis of direct and indirect effects of explanatory variables and exploratory service innovation.

\begin{tabular}{|c|c|c|c|c|c|c|c|c|c|c|c|c|}
\hline & $\begin{array}{c}1 \\
\text { innovation }\end{array}$ & $\begin{array}{c}2 \\
\text { innovation }\end{array}$ & $\begin{array}{c}3 \\
\text { innovation }\end{array}$ & $\begin{array}{c}4 \\
\text { explicit }\end{array}$ & $\begin{array}{c}5 \\
\text { explicit }\end{array}$ & $\begin{array}{c}6 \\
\text { tacit }\end{array}$ & $\begin{array}{c}7 \\
\text { tacit }\end{array}$ & $\begin{array}{c}8 \\
\text { innovation }\end{array}$ & $\begin{array}{c}9 \\
\text { innovation }\end{array}$ & $\begin{array}{c}10 \\
\text { innovation }\end{array}$ & $\begin{array}{c}11 \\
\text { innovation }\end{array}$ & $\begin{array}{c}12 \\
\text { innovation }\end{array}$ \\
\hline Gender & $-0.411^{\star *}$ & $-0.127^{\star *}$ & $-0.100^{* *}$ & -0.012 & -0.037 & $-0.190^{\star *}$ & $-0.209^{* *}$ & $-0.093^{\star *}$ & $-0.035^{\star *}$ & $-0.028^{\star *}$ & -0.049 & $-0.119^{* *}$ \\
\hline Age & $-0.216^{\star *}$ & $-0.066^{\star}$ & -0.011 & 0.060 & $0.121^{\star *}$ & $-0.069^{*}$ & -0.013 & $-0.055^{*}$ & -0.010 & $-0.055^{* *}$ & -0.035 & -0.004 \\
\hline Education & $0.280^{* *}$ & $0.119^{* *}$ & $0.105^{\star *}$ & 0.037 & $0.136^{* *}$ & -0.003 & $0.085^{\star *}$ & $0.118^{\star *}$ & 0.033 & $0.144^{\star *}$ & $0.148^{\star *}$ & $0.257^{\star *}$ \\
\hline Years & -0.017 & 0.020 & 0.014 & $-0.184^{* *}$ & $-0.177^{\star *}$ & -0.038 & $-0.032^{\star}$ & $0.030^{*}$ & 0.016 & 0.043 & 0.039 & 0.038 \\
\hline Transformational & & $0.846^{* *}$ & & $0.724^{\star *}$ & & $0.814^{\star *}$ & & $0.686^{* *}$ & & & & \\
\hline Idealized & & & $0.569^{* *}$ & & 0.083 & & $0.158^{* *}$ & & $0.660^{\star *}$ & & & \\
\hline Intellectual & & & $0.085^{* *}$ & & 0.045 & & $0.095^{\star *}$ & & & $0.069^{*}$ & & \\
\hline Inspirational & & & 0.029 & & $0.236^{* *}$ & & $0.209^{\star *}$ & & & & $0.165^{\star *}$ & \\
\hline Individualized & & & $0.332^{\star *}$ & & $0.497^{\star *}$ & & $0.519^{* *}$ & & & & & $0.506^{\star *}$ \\
\hline Explicit & & & & & & & & 0.021 & & & & \\
\hline Tacit & & & & & & & & $0.178^{*}$ & $0.298^{* *}$ & $797^{* *}$ & $0.697^{\star *}$ & $0.360^{* *}$ \\
\hline $\mathrm{F}$ & $19.804^{*}$ & $276.40^{* *}$ & $292.05^{* *}$ & $73.53^{* *}$ & $55.241^{* *}$ & $207.76^{* *}$ & $166.69^{* *}$ & $208.21^{* *}$ & $313.25^{* *}$ & $17.932^{* *}$ & $135.24^{* *}$ & $184.05^{* *}$ \\
\hline $\mathrm{R}^{2}$ & 0.237 & 0.845 & 0.903 & 0.591 & 0.638 & 0.804 & 0.842 & 0.853 & 0.881 & 0.032 & 0.762 & 0.814 \\
\hline $\operatorname{adj} . R^{2}$ & 0.225 & 0.843 & 0.900 & 0.583 & 0.626 & 0.800 & 0.837 & 0.848 & 0.879 & 0.019 & 0.757 & 0.809 \\
\hline
\end{tabular}

${ }^{* *}: p<0.01 ; *: p<0.05$. 
Table 3. Analysis of direct and indirect effects of explanatory variables and exploitative service innovation.

\begin{tabular}{|c|c|c|c|c|c|c|c|c|c|c|c|c|}
\hline & $\begin{array}{c}1 \\
\text { innovation }\end{array}$ & $\begin{array}{c}2 \\
\text { innovation }\end{array}$ & $\begin{array}{c}3 \\
\text { innovation }\end{array}$ & $\begin{array}{c}4 \\
\text { explicit }\end{array}$ & $\begin{array}{c}5 \\
\text { explicit }\end{array}$ & $\begin{array}{c}6 \\
\text { tacit }\end{array}$ & $\begin{array}{c}7 \\
\text { tacit }\end{array}$ & $\begin{array}{c}8 \\
\text { innovation }\end{array}$ & $\begin{array}{c}9 \\
\text { innovation }\end{array}$ & $\begin{array}{c}10 \\
\text { innovation }\end{array}$ & $\begin{array}{c}11 \\
\text { innovation }\end{array}$ & $\begin{array}{c}12 \\
\text { innovation }\end{array}$ \\
\hline Gender & $-0.342^{* *}$ & $-0.122^{*}$ & $-0.128^{* *}$ & -0.012 & -0.037 & $-0.190^{* *}$ & $-0.209^{* *}$ & $-0.159^{* *}$ & $-0.216^{* *}$ & $-0.164^{* *}$ & $-0.154^{* *}$ & $-0.138^{* *}$ \\
\hline Age & $-0.193^{* *}$ & $-0.076^{* *}$ & $0.005^{*}$ & 0.060 & $0.121^{* *}$ & $-0.069^{*}$ & -0.013 & $-0.129^{* *}$ & $-0.081^{*}$ & $-0.142^{\star *}$ & $-0.128^{* *}$ & -0.059 \\
\hline Education & $0.250^{* *}$ & $0.125^{* *}$ & $0.206^{* *}$ & 0.037 & $0.136^{* *}$ & -0.003 & $0.085^{* *}$ & $0.102^{*}$ & $0.233^{* *}$ & $0.128^{* *}$ & $0.121^{\star *}$ & $0.202^{* *}$ \\
\hline Years & $0.039^{*}$ & $0.067^{* *}$ & $0.071^{\star *}$ & $-0.184^{* *}$ & $-0.177^{\star *}$ & -0.038 & $-0.032^{*}$ & $0.169^{* *}$ & $0.171^{\star *}$ & 0.191 & $0.180^{* *}$ & $0.151^{\star *}$ \\
\hline $\begin{array}{c}\text { Transforma- } \\
\text { tional }\end{array}$ & & $0.655^{\star *}$ & & $0.724^{\star *}$ & & $0.814^{* *}$ & & $0.408^{\star *}$ & & & & \\
\hline Idealized & & & $0.250^{* *}$ & & 0.083 & & $0.158^{* *}$ & & $0.539^{* *}$ & & & \\
\hline Intellectual & & & -0.036 & & 0.045 & & $0.095^{\star *}$ & & & -0.013 & & \\
\hline Inspirational & & & 0.038 & & $0.236^{\star *}$ & & $0.209^{* *}$ & & & & $0.105^{*}$ & \\
\hline Individualized & & & $0.492^{* *}$ & & $0.497^{* *}$ & & $0.519^{* *}$ & & & & & $0.394^{\star *}$ \\
\hline Explicit & & & & & & & & $0.604^{* *}$ & $0.588^{* *}$ & $0.709^{* *}$ & $0.640^{* *}$ & $0.416^{* *}$ \\
\hline Tacit & & & & & & & & -0.234 & & & & \\
\hline $\mathrm{F}$ & $12.836^{\star *}$ & $57.637^{\star *}$ & $49.439^{* *}$ & $70.53^{\star *}$ & $55.241^{\star *}$ & $207.76^{\star *}$ & $166.69^{* *}$ & $62.688^{* *}$ & $73.554^{\star *}$ & $61.520^{* *}$ & $63.115^{\star *}$ & $81.34^{\star *}$ \\
\hline $\mathrm{R}^{2}$ & 0.168 & 0.532 & 0.612 & 0.591 & 0.638 & 0.804 & 0.842 & 0.635 & 0.671 & 0.593 & 0.599 & 0.659 \\
\hline adj. $R^{2}$ & 0.155 & 0.522 & 0.599 & 0.583 & 0.626 & 0.800 & 0.837 & 0.625 & 0.662 & 0.584 & 0.590 & 0.650 \\
\hline
\end{tabular}

$* *: p<0.01 ; *: p<0.05$.

tant impact on service innovation. However, four dimensions of leadership have different impacts on service innovation. This paper demonstrates the need to split transformational leadership constructs into four dimensions.

\subsection{Limitation and Future Research}

Limitation. First, the paper lacks attention to the external environment variables. The uncertainty of external environment has a great influence on transformational leadership and government service innovation. Second, the paper lacks effective panel data. Small sample surveys are hard to convince. Third, the paper lacks dynamic display. This research mainly shows causal relationship, which is how each variable dynamic work lacks enough display.

Future research. First, more attention will be paid to the influence of external environment. Second, future research should select panel data to study the issue, thus making the results more convincing. Third, future research should adopt a case study approach to demonstrate dynamic processes.

\section{References}

Barbuto, J. E., \& Burbach, M. E. (2006). The Emotional Intelligence of Transformational Leaders: A Field Study of Elected Officials. The Journal of Social Psychology, 146, 5164. https://doi.org/10.3200/SOCP.146.1.51-64

Bennis, W. G., \& Nanus, B. (1985). Leaders. The Strategies for Taking Charge. New York: Harper and Row.

Birkinshaw, J. (2001). Capability Management in Network Organizations. Administrative Science Quarterly, 46, 41-54. 
Bloodgood, J. M., \& Salisbury, W. D. (2001). Understanding the Influence of Organizational Change Strategies on Information Technology and Knowledge Management Strategies. Decision Support Systems, 31, 55-69.

Borins, S. F. (2012). Making Narrative Count: A Narratological Approach to Public Management Innovation. Journal of Public Administration Research \& Theory, 22, 165189. https://doi.org/10.1093/jopart/muq088

Cai, Y. H., Jia, L. D., \& Ye, Y. (2013). The Influence of Differentiated Transformational Leadership on Knowledge Sharing and Team Creativity: Interpretation of Social Network Mechanism. Journal of Mental Science, 45, 585-598.

Burns, J. M. (1978). Leadership. New York, NY: Harper \& Row.

Bass, B. M. (1985). Leadership and Performance beyond Expectations. New York: Free Press.

Berry, F. S. (1994). Innovation in Public Management: The Adoption of Strategic Planning. Public Administration Review, 54, 322. https://doi.org/10.2307/977379

Barzelay, M., \& Jacobsen, A. S. (2009). Theorizing Implementation of Public Management Policy Reforms: A Case Study of Strategic Planning and Programming in the European Commission. Governance, 22, 319-334. https://doi.org/10.1111/j.1468-0491.2009.01437.x

Damanpour, F. (1988). Innovation Type, Radicalness, and the Adoption Process. Communication Research, 15, 545-567. https://doi.org/10.1177/009365088015005003

De Vries, H., Bekkers, V., \& Tummers, L. (2015). Innovation in the Public Sector: A Systematic Review and Future Research Agenda. Public Administration, 94, 146-166. https://doi.org/10.1111/padm.12209

Fernandez, S. (2004). Developing and Testing an Integrative Framework of Public Sector Leadership: Evidence from the Public Education Arena. Journal of Public Administration Research \& Theory, 15, 197-217. https://doi.org/10.1093/jopart/mui014

Girard, J. P., \& McIntyre, S. (2010). Knowledge Management Modeling in Public Sector Organizations: A Case Study. International Journal of Public Sector Management, 23, 71-77. https://doi.org/10.1108/09513551011012330

Hartley, J. (2005). Innovation in Governance and Public Services: Past and Present. Public Money and Management, 25, 27-34.

Harvey, G., Skelcher, C., Spencer, E. et al. (2010). Absorptive Capacity in a Non-Market Environment: A Knowledge-Based Approach to Analyzing the Performance of Sector Organizations. Public Management Review, 12, 77-97. https://doi.org/10.1080/14719030902817923

Jansen, J. J. P., Vera, D., \& Crossan, M. (2009). Strategic Leadership for Exploration and Exploitation: The Moderating Role of Environmental Dynamism. The Leadership Quarterly, 20, 5-18.

Kark, R., \& Shamir, B. (2002). The Influence of Transformational Leadership on Followers' Relational versus Collective Self-Concept. Academy of Management Annual Meeting Proceedings, No. 1, D1-D6.

Kim, H. (2014). Transformational Leadership, Organizational Clan Culture, Organizational Affective Commitment, and Organizational Citizenship Behavior: A Case of South Korea's Public Sector. Public Organization Review, 14, 397-417. https://doi.org/10.1007/s11115-013-0225-Z

Mol, M. J. (2008). Giant Steps in Management: Creating Innovations That Change the Way We Work. Monthly Notices of the Royal Astronomical Society, 369, 1858-1868.

Nonaka, I., \& Toyama, R. (1995). A Theory of Organizational Knowledge Creation. In- 
ternational Journal of Technology Management, 11, 833-845.

Pinjani, P., \& Palvia, P. (2013). Trust and Knowledge Sharing in Diverse Global Virtual Teams. Information \& Management, 50, 144-153.

Popadiuk, S., \& Choo, C. W. (2006). Innovation and Knowledge Creation: How Are These Concepts Related. International Journal of Information Management, 26, 302312.

Reagans, R., \& McEvily, B. (2003). Network Structure and Knowledge Transfer: The Effects of Cohesion and Range. Administrative Science Quarterly, 48, 240-267. https://doi.org/10.2307/3556658

Richards, G. S., \& Duxbury, L. (2015). Work-Group Knowledge Acquisition in Knowledge Intensive Public-Sector Organizations: An Exploratory Study. Journal of Public Administration Research and Theory, 25, 1247-1277. https://doi.org/10.1093/jopart/muu034

Sosik, J. J., Avolio, B. J., \& Kahai, S. S. (1997). Effects of Leadership Style and Anonymity on Group Potency and Effectiveness in a Group Decision Support System Environment. Journal of Applied Psychology, 82, 89-103.

https://doi.org/10.1037/0021-9010.82.1.89

Tan, X., Huang, C., \& Liu, B. (2016). Research on the Effect Mechanism of Government Departments' Innovation Performance under Knowledge Management. Soft Science, 30, 22-25.

Titi Amayah, A. (2013). Determinants of Knowledge Sharing in a Public Sector Organization. Journal of Knowledge Management, 17, 454-471.

https://doi.org/10.1108/JKM-11-2012-0369

Valle, S., \& Vázquez-Bustelo, D. (2009). Concurrent Engineering Performance: Incremental versus Radical Innovation. International Journal of Production Economics, 119, 136-148.

Vera, D., \& Crossan, M. (2004). Strategic Leadership and Organizational Learning. Academy of Management Review, 29, 222-240.

Waldman, D. A., \& Yammarino, F. J. (1999). CEO Charismatic Leadership: Levels-ofManagement and Levels-of-Analysis Effects. Academy of Management Review, 24, 266-285.

Wen, L. (2014). Research on Motivation and Mechanism of Local Government Innovation. Zhejiang: Zhejiang University.

Wright, B. E., Moynihan, D. P., \& Pandey, S. K. (2012). Pulling the Levers: Transformational Leadership, Public Service Motivation, and Mission Valence. Public Administration Review, 72, 206-215. https://doi.org/10.1111/j.1540-6210.2011.02496.x

Wu, J., Ma, L., \& Su, T. (2011). Types and Characteristics of Government Innovation-A Case Study Based on the "China Local Government Innovation Award" Project. Journal of Public Administration, 8, 94-103.

$\mathrm{Yu}, \mathrm{K}$. (2006). Chinese Civil Society: Concept, Classification and Institutional Environment. Chinese Social Sciences, No. 1, 109-122. 
Submit or recommend next manuscript to SCIRP and we will provide best service for you:

Accepting pre-submission inquiries through Email, Facebook, LinkedIn, Twitter, etc. A wide selection of journals (inclusive of 9 subjects, more than 200 journals)

Providing 24-hour high-quality service

User-friendly online submission system

Fair and swift peer-review system

Efficient typesetting and proofreading procedure

Display of the result of downloads and visits, as well as the number of cited articles Maximum dissemination of your research work

Submit your manuscript at: http://papersubmission.scirp.org/

Or contact ojl@scirp.org 